\title{
GEOCHEMICAL ANALYSIS OF SILICEOUS SEDIMENTS FROM VASILIKA, NORTHERN GREECE
}

\author{
Karageorgiou S. ${ }^{1}$, Vavelidis M. ${ }^{1}$, Andreou S. ${ }^{2}$ and Melfos V. ${ }^{1}$ \\ ${ }^{1}$ Aristotle University of Thessaloniki, School of Geology, Department of Mineralogy-Petrology- \\ Economic Geology, 54124, Thessaloniki, Greece, matina_mk@hotmail.com, \\ vavelidi@geo.auth.gr,melfosv@geo.auth.gr \\ ${ }^{2}$ Aristotle University of Thessaloniki, Faculty of Philosophy School of History and Archaeology, \\ 54124 Thessaloniki, Greece, andrest@hist.auth.gr
}

\begin{abstract}
The present paper presents new mineralogical and geochemical data of the siliceous sediments from the region of Vasilika in northern Greece. The studied material consists of reddish and brownish cherts and jaspers containing mostly microcrystalline quartz and Fe-oxides. Chemical analysis has been carried out, including the identification of major oxides, trace elements and REE, in order to determine their geotectonic affinity based on the correlation of immobile trace element distribution. The geochemical features combined with the mineralogical composition of these siliceous sediments indicate that they were formed as the result of a hydrothermal circulating convection system near a mid-ocean ridge. Rare earth elements (REE) are regarded as the most reliable immobile elemental components in the complex geological process of the sedimentary cycle because they are relatively stable during post-depositional processes such as diagenesis, alteration and weathering. In addition Ce anomaly can help to establish the marine environment in which cherts were formed.
\end{abstract}

Keywords: chert, jasper, Ce anomaly, REE, hydrothermal sediments.

\section{Пєрí}

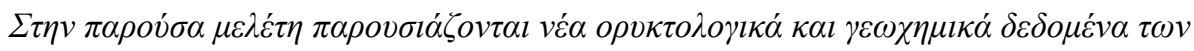

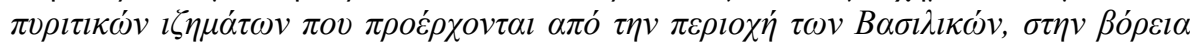

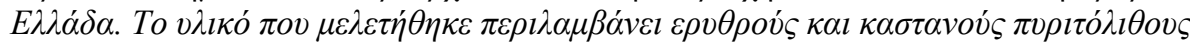

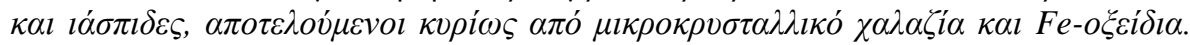

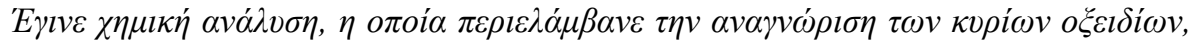

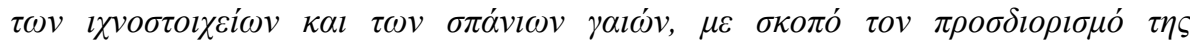

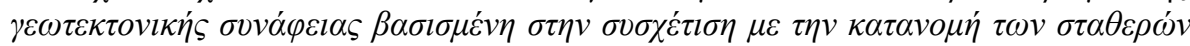

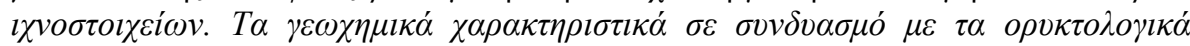

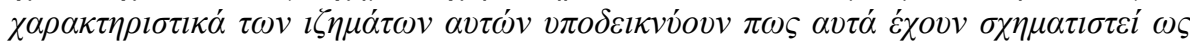

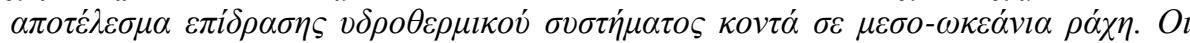

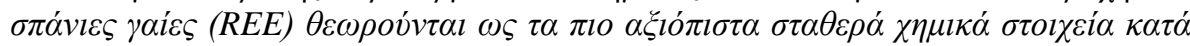

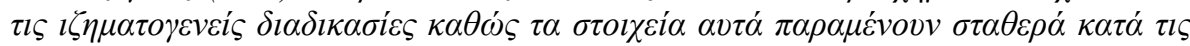

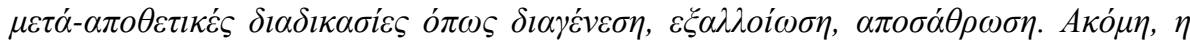

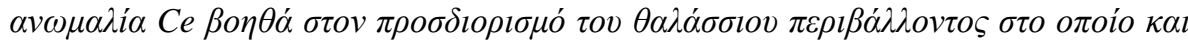

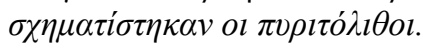

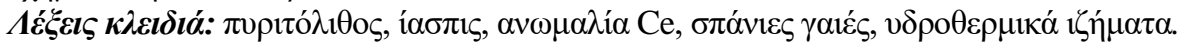




\section{Introduction}

Siliceous sediments are dominantly composed of $\mathrm{SiO}_{2}$ minerals such as quartz, chalcedony and opal. These sedimentary rocks are very hard and fine-grained. The term chert is used as a group name for siliceous sedimentary rocks (Boggs, 2005). Chert is a high-silica rock, consisting mainly of cryptocrystalline or microcrystalline quartz. Other siliceous sediments such as flint, jasper, and chalcedony are considered to be chert, despite the distinct differences among them (Cradell, 2005). Chert and other related siliceous sediments were among the first raw materials utilized in prehistory for the manufacture of knapped tools (Rapp, 2009).

In this study siliceous sediments from the region of Vasilika, in northern Greece are studied in terms of mineralogy and geochemistry. In this location there is evidence for prehistoric quarrying activity and exploitation of these raw materials for the construction of knapped tools. Such evidence is mentioned by Grammenos et al. (1992) at a distance of approximately $2.5 \mathrm{~km}$ north of the Neolithic settlement of Thermi, in the site of Kiparissi. A link between the settlement of Thermi and the quarrying activity in Vasilika in Neolithic (7,000-3,000 BCE) and Early Bronze Age (3,000-1,800 $\mathrm{BCE})$, has been suggested for the procurement of chert.

The aim of this study is to identify the geochemical context of these raw materials and examine especially the distribution of the rare earth elements (REE) and how they can be applied for the identification model of the formation of these sediments.

\section{Geological setting}

The area of Vasilika is located $28 \mathrm{~km}$ southeast of the city of Thessaloniki, at the upstream part of the Anthemountas basin, at the boundary between the Vardar zone and the Circum Rhodope belt. The area is dominated by an ophiolite outcrop, part of the Chalkidiki ophiolite complex. This ophiolite complex has a NW-SE direction and is considered as a detached block of the Vardar oceanic crust, consisting of dismembered bodies which display tectonic contacts with the country rocks. Other ophiolites outcrops occur in Triadi, Galatista, Vavdos, Gerakini, Metamorphosis and Toroni, in Chalkidiki. The Vasilika ophiolite includes mainly pyroxenites, dunites, peridotites, gabbros and serpentinites, with magnesite and chromium occurrences (Fig.2). Chromium deposits are hosted in the ultramafic unit of the ophiolitic complex forming mainly massive stratiform ore bodies in dunites (Christodoulou and Michailidis, 1990). Dunites are the dominant ultramafic rocks in Vasilika area and are serpentinized (Christofides et al., 1994).

The emplacement of the Vardar oceanic crust on to the continental margin took place in the Upper Jurassic-Lower Cretaceous, which is confirmed by the existence of fossils in the sediments which interfere in pillow lavas (Spray et al., 1984). The tectonic contacts between ophiolites and the neighbouring rock formations represent thrust faults. According to Jung et al. (1980) the ophiolite complex is considered to be allochthonous. However, it has also been proposed a theory of autochthonous character (Bebien et al., 1986).

\section{Materials and Methods}

Twelve samples of siliceous sediments were collected from the study area after a regional fieldwork focusing on a geological-archaeological survey in the frame of a combined project at Anthemountas basin, among the Aristotle University of Thessaloniki, the Ephorate of Antiquities of Thessaloniki City and the Poznan University (Poland). The samples represent the raw materials that prehistoric man utilized for the manufacture of lithic tools and they are connected with the quarrying activity at the region. 


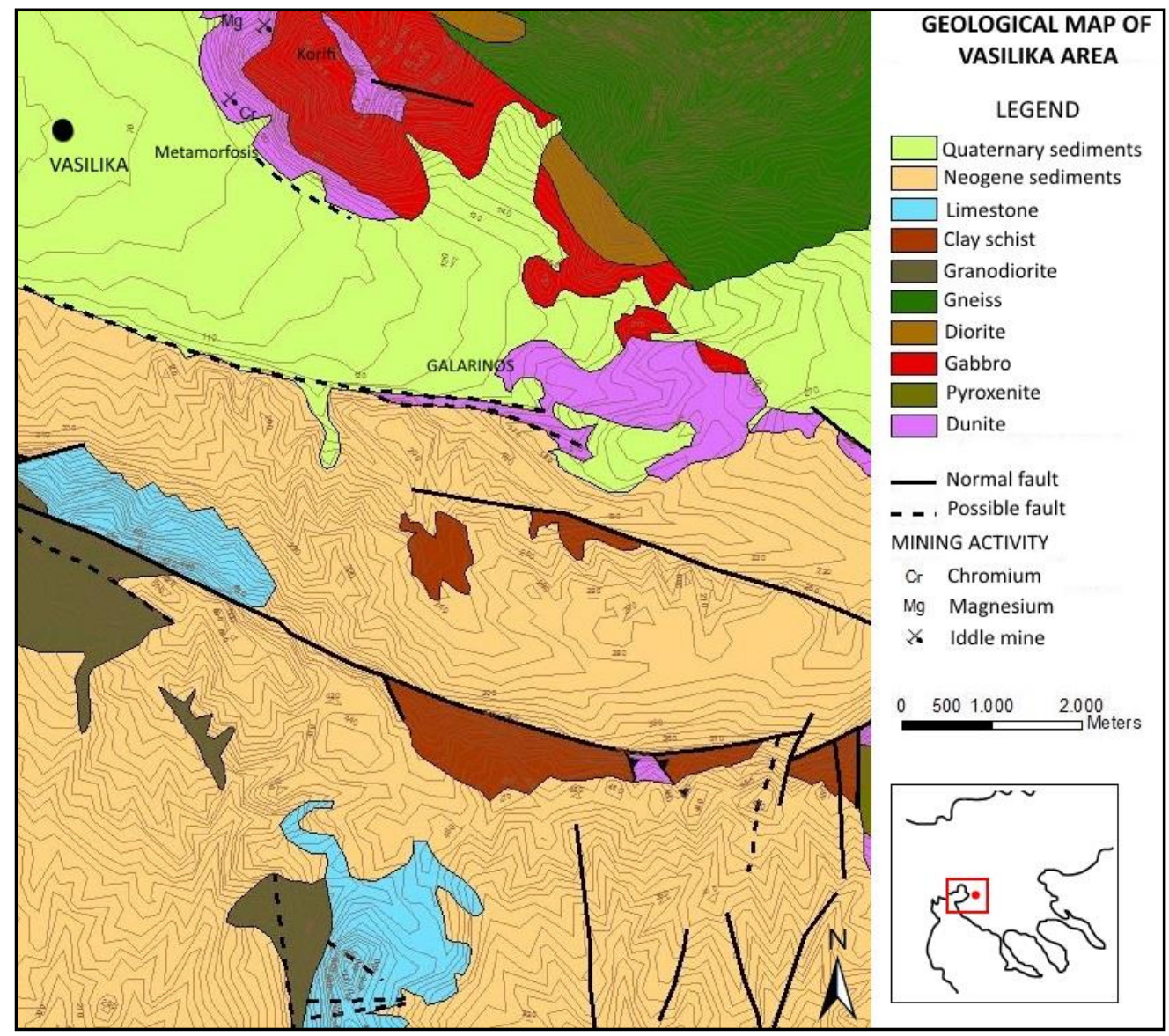

Figure 1 - Geological map of Vasilika region. Modified after Mollat et al. (1978).

The macroscopic examination of the sediments was mainly based on colour, texture and translucency characteristics of the rock samples. The colour characterization was based on the Munsell soil colour chart. In order to identify the mineralogical composition and the rock textures of the cherts optical microscopy was applied by using a polarizing microscope at the Department of Mineralogy-Petrology-Economic Geology at the School of Geology, Aristotle University of Thessaloniki.

The determination of the major, trace and rare earth elements (REE) was achieved by inductively coupled plasma mass spectrometry (ICP-MS) at the ACME Analytical Labs (Bureau Veritas), in Vancouver, Canada. This method is mainly preferred due to the effective detection abilities. For this study the samples were dissolved by using multiple acids (multi-acid digestion) with Ultra Trace ICP-MS analysis. The quantity of each sample was $0.5 \mathrm{gr}$. The samples were heated at $\mathrm{t}=150^{\circ} \mathrm{C}$ in a solution form, using $\mathrm{HNO}_{3}-\mathrm{HF}-\mathrm{HCLO}_{4}$. After drying, the residual samples were dissolved in $6 \mathrm{~N}$ HCL. The REE concentrations of the analysed cherts were normalized compared to the prototype sample of PAAS (Post-Archaean Australian Shale Average) which is the most common standard for modern sea water and ocean sediments.

$\mathrm{X}$-ray fluorescence (XRF) analysis was applied in order to identify the major oxides in the cherts. The samples were pulverized and then were prepared in order to construct fused beads. The powder was mixed with $\mathrm{Li}_{2} \mathrm{~B} 4 \mathrm{O}_{7}$ and was fused at a temperature of $1100^{\circ}-1200^{\circ} \mathrm{C}$. The ratio of each sample in the Li borate was 1:8. 


\section{Results}

The colour characterization of the studied cherts showed four main categories which are: (i) reddish brown-dark reddish brown, (ii) brown, (iii) yellow-red and (iv) dusky red (Fig.2). The most prominent type is brown-dark reddish brown, with 8 out of 12 samples. The samples with a lighter colour, such as yellow-red colour, include darker veins which consist of Fe and Mn oxides. Five out of twelve samples have dark spots on the surface indicating a thermal effect. This could be the result of a heat treatment applied by prehistoric man during the process of collecting raw materials or during manufacturing lithic tools, or because of an accidental fire.

Mineralogical and petrographic analysis under the polarizing microscope showed that the cherts are fine-grained consisting mainly of microcrystalline quartz and some chalcedony spheroids. The grain size of the quartz grains range from 1 to $10 \mu \mathrm{m}$. Additionally, there are minor accessory minerals consisting of Fe-oxides. Due to the presence of Fe-oxides, the microcrystals of quartz have acquired a reddish hue (Fig.3).

The analytical results for the studied cherts show that $\mathrm{SiO}_{2}$ varies between 88 and 92 wt $\%$ whereas $\mathrm{FeO}$ ranges from 4 to $10 \mathrm{wt} \%$. $\mathrm{SiO}_{2}$ is negatively correlated to $\mathrm{Al}_{2} \mathrm{O}_{3}$. The $\mathrm{Si}-\mathrm{Al}$ diagram proposed by Crerar et al. (1982) shows that the Vasilika chert samples are connected with a hydrothermal source (Fig.4). The ratio of $\mathrm{Al} /(\mathrm{Al}+\mathrm{Fe}+\mathrm{Mn})$ is $0.08-0.13$ which shows the correlation of the cherts to a hydrothermal circulating convection system. According to Yamamoto (1986) these value of $\mathrm{Al} /(\mathrm{Al}+\mathrm{Fe}+\mathrm{Mn})$ ratio indicate a hydrothermal contribution to the ocean sediments. Trace element geochemistry of the cherts is dominantly based on the study of $\mathrm{Cu}, \mathrm{Co}, \mathrm{Ni}, \mathrm{As}, \mathrm{Ag}, \mathrm{Ba}, \mathrm{B}, \mathrm{Sb}$ and $\mathrm{U}$ (Junguo et al., 2011). The maximum value of Ni/Co ratio for cherts of a hydrothermal origin is 3.6 (Crerar et al., 1982). The Ni/Co ratio of the Vasilika chert is 3.0.

The $\mathrm{Al}_{2} \mathrm{O}_{3} /\left(\mathrm{Al}_{2} \mathrm{O}_{3}+\mathrm{Fe}_{2} \mathrm{O}_{3}\right)$ ratio is from 0.11 to 0.19 indicating a mid-ocean ridge geotectonic environment (Murray et al., 1990). The discrimination diagrams of $100 \times\left(\mathrm{Fe}_{2} \mathrm{O}_{3} / \mathrm{SiO}_{2}\right)$ versus $100 \times\left(\mathrm{Al}_{2} \mathrm{O}_{3} / \mathrm{SiO}_{2}\right)\left(\right.$ Fig.5), $\mathrm{Fe}_{2} \mathrm{O}_{3} /\left(100-\mathrm{SiO}_{2}\right)$ versus $\mathrm{Al}_{2} \mathrm{O}_{3} /\left(100-\mathrm{SiO}_{2}\right)\left(\right.$ Fig.6) and $\mathrm{Fe}_{2} \mathrm{O}_{3} / \mathrm{TiO}_{2}$ versus $\mathrm{Al}_{2} \mathrm{O}_{3} /\left(\mathrm{Al}_{2} \mathrm{O}_{3}+\mathrm{Fe}_{2} \mathrm{O}_{3}\right)$ (Fig.7) show the plot areas of siliceous sediments at various geotectonic environments such as continental margins, ocean ridges and ocean basins, according to Murray (1994). The chert samples from Vasilika plot in the ocean ridge areas of these diagrams, or very close to them. The high $\mathrm{SiO}_{2}$ content and the very low concentrations of the rest elements affect the plot of the samples in these diagrams and so a slight deviation may be observed in the diagrams.

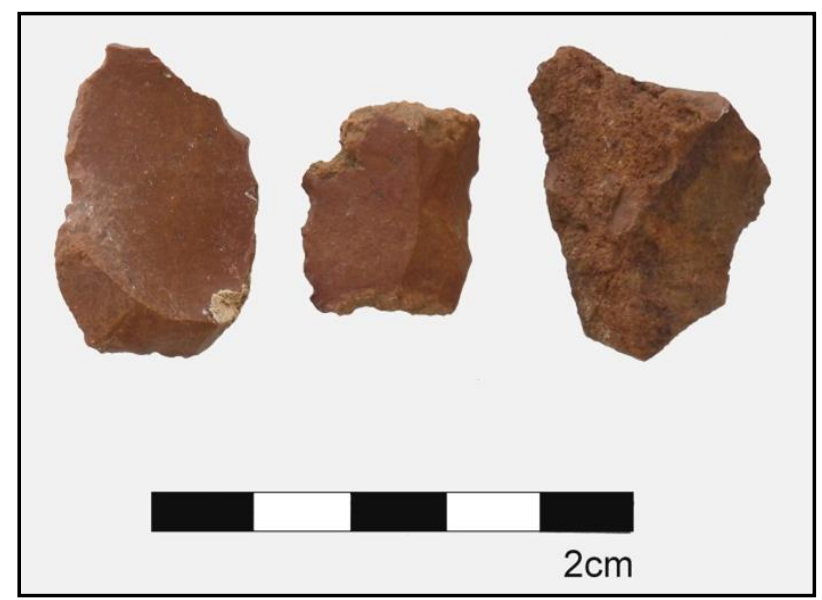

Figure 2 - Raw materials of reddish brown cherts from Vasilika. 


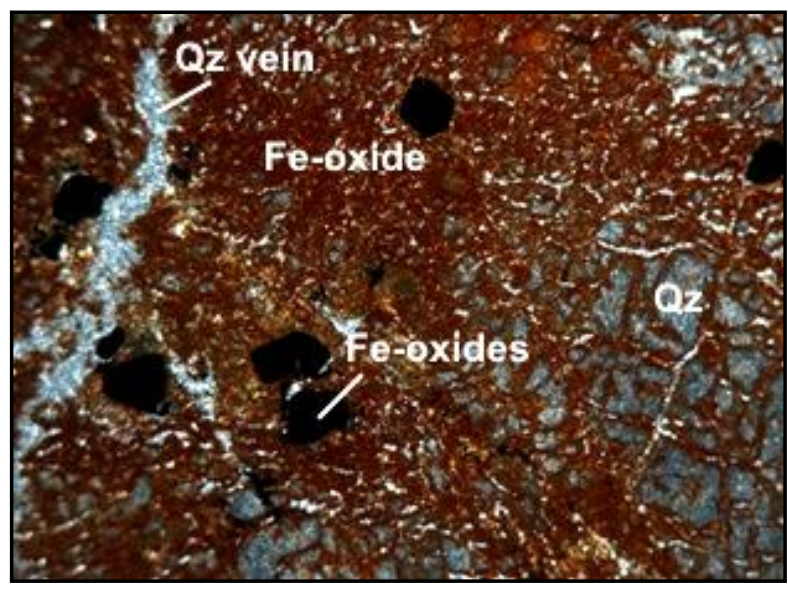

Figure 3 - Thin section of chert from Vasilika, under crossed polarized light. Chert mainly consists of microcrystalline quartz and Fe-oxides (magnification $x 5$, the large side of the photo corresponds to $2.8 \mathrm{~mm}$ ).

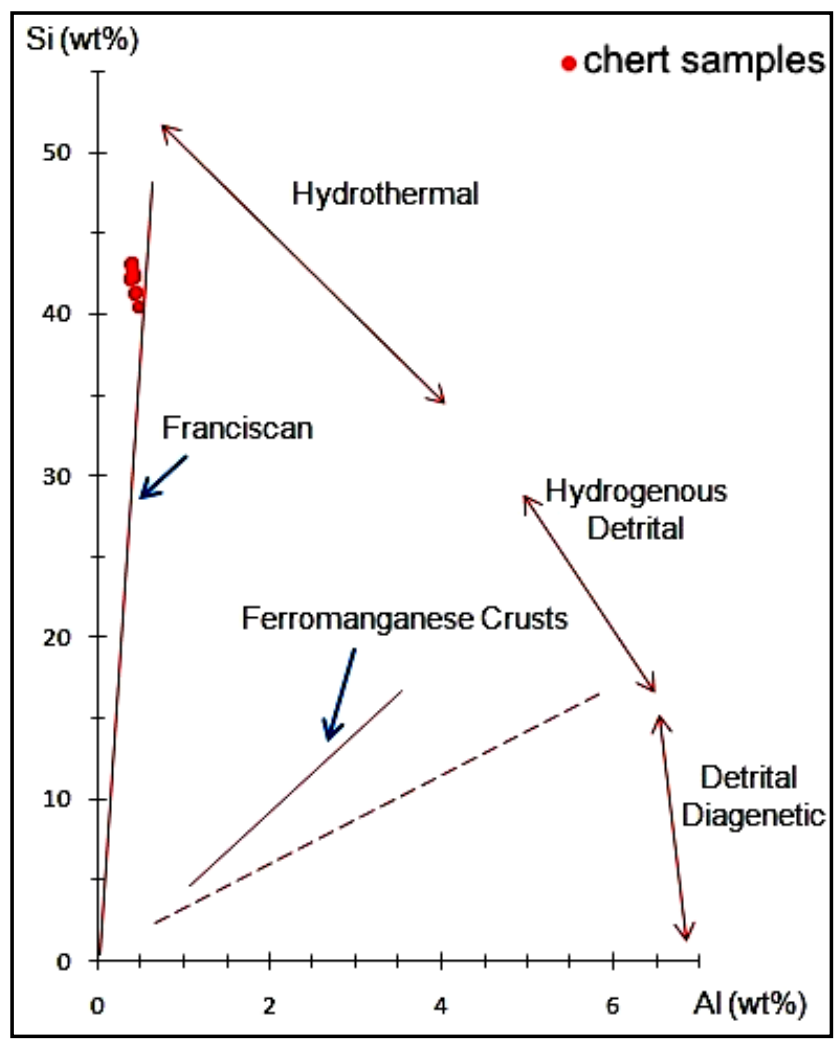

Figure 4 - Si-Al diagram (modified after Crerar et al., 1982). Cherts from Vasilika are connected to a hydrothermal system. 


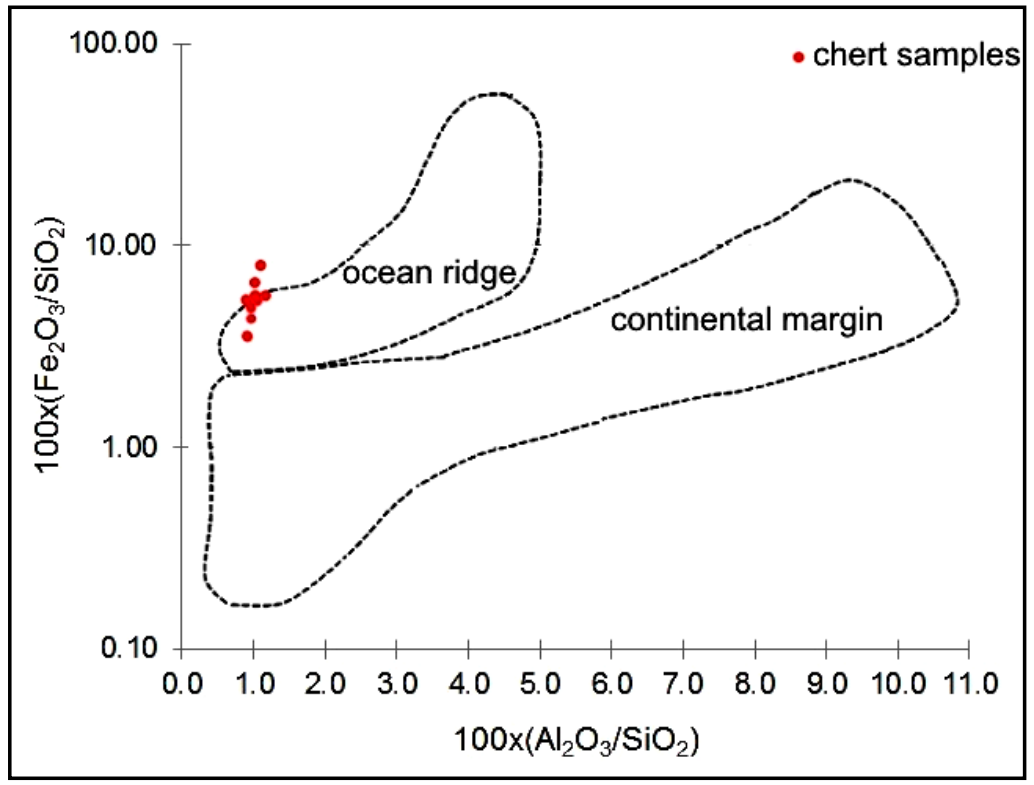

Figure 5 - 100x $\left(\mathrm{Fe}_{2} \mathrm{O}_{3} / \mathrm{SiO}_{2}\right)-100 x\left(\mathrm{Al}_{2} \mathrm{O}_{3} / \mathrm{SiO}_{2}\right)$ diagram (modified after Murray, 1994) showing samples from Vasilika related to ocean ridge area.

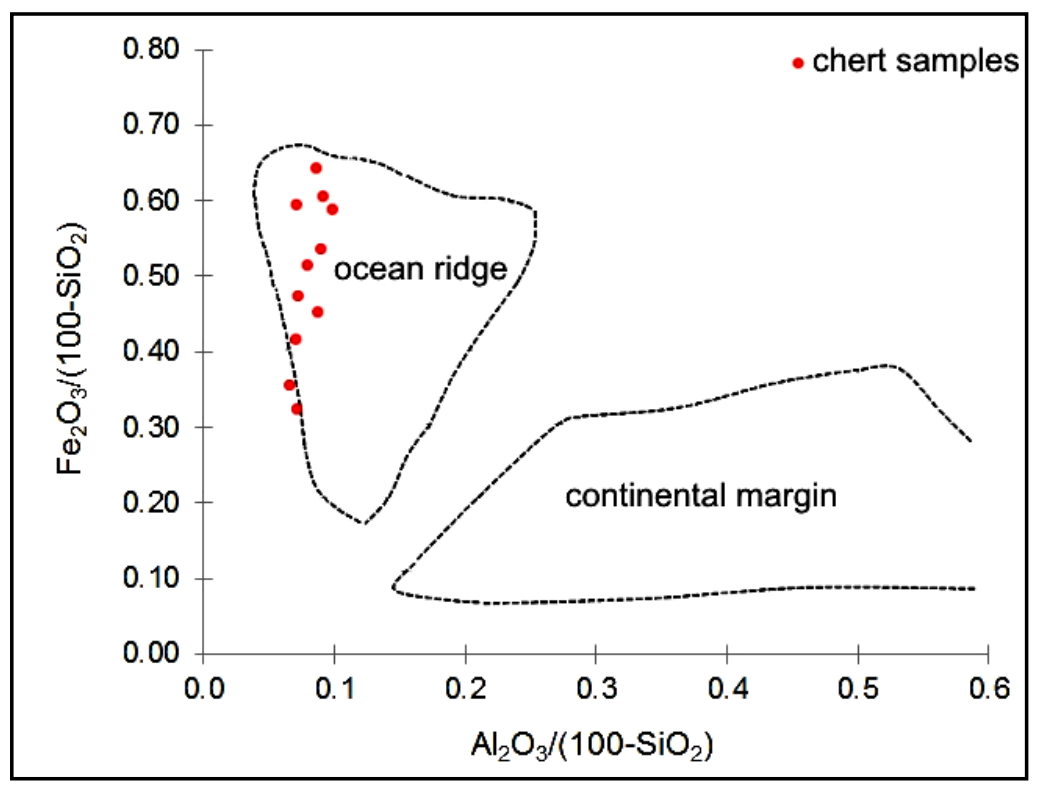

Figure $6-\mathrm{Fe}_{2} \mathrm{O}_{3} /\left(100-\mathrm{SiO}_{2}\right)-\mathrm{Al}_{2} \mathrm{O}_{3} /\left(100-\mathrm{SiO}_{2}\right)$ diagram (modified after Murray, 1994). The samples appear at the ocean ridge province of the diagram.

The study of the REE in these cherts is mostly based to the estimation of Ce anomaly. $\mathrm{Ce}^{3+}$ has low ionization potential and as a result the cerium's behaviour differs from the rest REE. The Ce anomaly is defined by the equation: $\mathrm{Ce} / \mathrm{Ce}^{*}=\mathrm{Ce}_{\mathrm{N}} /\left[\left(\mathrm{La}_{\mathrm{N}}\right)\left(\mathrm{Pr}_{\mathrm{N}}\right)\right]^{1 / 2}$ where $\mathrm{Ce}^{*}$ is the hypothetical concentration of $\mathrm{Ce}^{3+}$ or: $\mathrm{Ce} / \mathrm{Ce}^{*}=2 \mathrm{Ce}_{\mathrm{N}} /\left(\mathrm{La}_{\mathrm{N}}+\mathrm{Pr}_{\mathrm{N}}\right)$ (Kato et al., 2009). $\mathrm{N}$ stands for the normalized values. The ratio of $\mathrm{Ce} / \mathrm{Ce}^{*}$ for the cherts from Vasilika is $0.62-1.78$ (Tab.1). Due to the capture of tetravalent $\mathrm{Ce}$ by the $\mathrm{Fe}-\mathrm{Mn}$ nodules there is a negative $\mathrm{Ce}$ anomaly in the sea water and a positive anomaly in the Fe-Mn minerals. Cerium anomaly is negative when siliceous sediments have been separated from the Fe-Mn minerals (Junguo et al., 2011). 
Table 1 - Ratios related to the REE study of cherts from Vasilika.

\begin{tabular}{|c|c|c|c|c|c|}
\hline & IREE & LREE & HREE & LREE/HREE & Ce/Ce* \\
\hline 17LV-1 & 0.17 & 0.09 & 0.08 & 1.21 & 1.32 \\
\hline 17LV-2 & 0.06 & 0.02 & 0.04 & 0.62 & 1.38 \\
\hline 17LV-4 & 0.01 & 0.01 & - & - & 1.44 \\
\hline 17LV-5 & 0.07 & 0.03 & 0.04 & 0.87 & 0.62 \\
\hline 17LV-6 & 0.16 & 0.03 & 0.13 & 0.26 & 0.77 \\
\hline 17LV-7 & 0.01 & 0.01 & - & - & 1.78 \\
\hline 17LV-8 & 0.02 & 0.02 & - & - & 1.39 \\
\hline 17LV-9 & 0.09 & 0.03 & 0.06 & 0.52 & 1.37 \\
\hline 17LV-10 & 0.11 & 0.07 & 0.04 & 2.06 & 1.25 \\
\hline 17LV-11 & 0.08 & 0.05 & 0.02 & 2.52 & 0.69 \\
\hline 17LV-12 & 0.11 & 0.06 & 0.06 & 0.97 & 0.72 \\
\hline
\end{tabular}

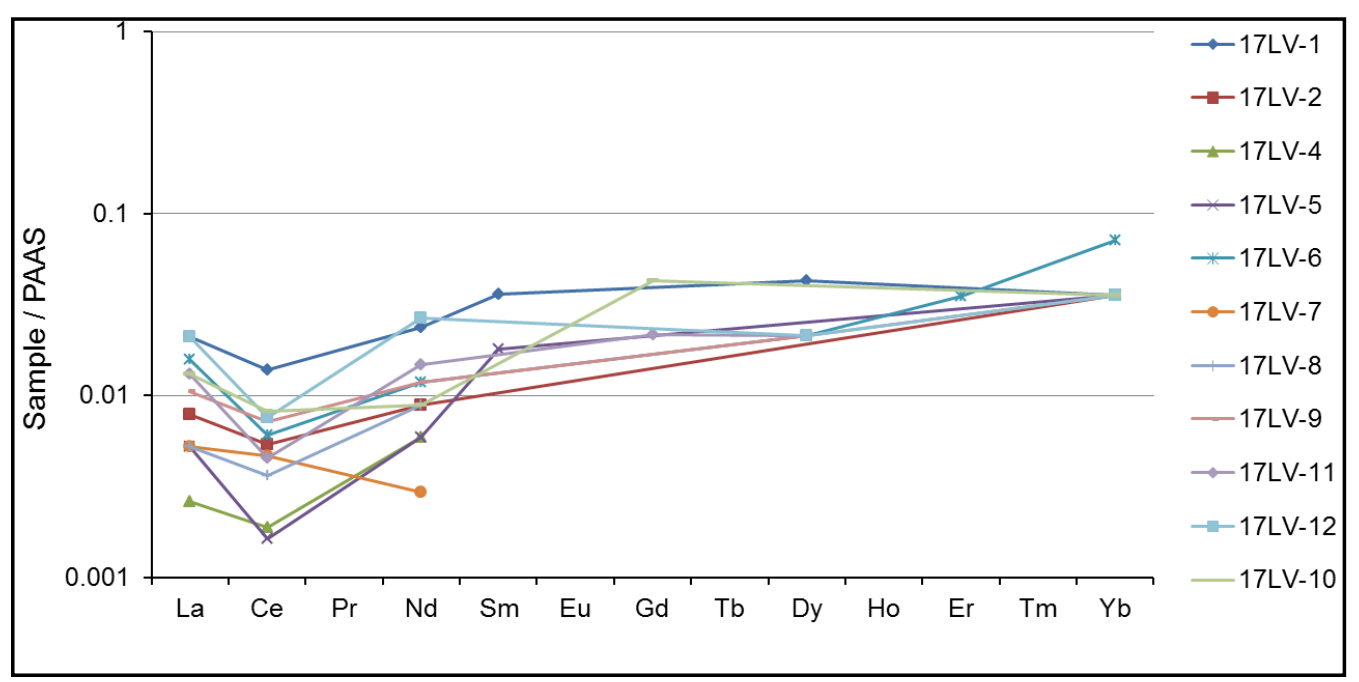

Figure 7 - REE diagram of Vasilika samples.

When there is mixing of the two, Ce-anomaly may be slightly negative up to slightly positive, as it has been identified in the case of the samples from Vasilika. Table 1 shows the sums and the ratios related to the REE study. When the HREE values are higher than the LREE, it is more likely for the silicate sediments to be related to an ocean basin. However, in the studied case, the LREE values are similar to the HREE although HREE are slightly more depleted than LREE. That is also an indicator of hydrothermal activity. $\Sigma$ REE is controlled by the influence degree of a continental input. The values of $\Sigma R E E$ tend to get higher from a mid-ocean ridge to a continental environment (Junguo et al., 2011). The depositional rate minimizes the exposure time of cherts to seawater and consequently the adsorption of REE resulting lower $\Sigma$ REE (Murray et al., 1990). Samples from Vasilika have low $\Sigma$ REE values which indicate low terrigenous content with a higher depositional rate in mid-ocean ridge.

\section{Conclusions}

After the petrographic and geochemical study of the siliceous sediments from Vasilika in northern Greece it was concluded that these are mainly reddish-brownish cherts which consist mainly of microcrystalline quartz with minor Fe-oxides. Major, trace and rare earth elements indicate the 
hydrothermal origin of these cherts. There is a correlation with a hydrothermal source near a midocean ridge geotectonic environment. The Ce anomaly reveals the mixing between siliceous sediments and Fe-Mn oxides, and its value differs, depending on the related geotectonic environment. Because of REE's immobility, these are used as geochemical tracers, giving a safe consideration on the origin of siliceous sediments.

\section{References}

Bebien, J., Baroz, J., Caperdi, S. and Venturelli, G., 1986. Magmatisme basique associe/es a l'ouverture d'un basin marginal dans les Hellenides internes au Jurassic, Ofioliti, 12, 53-70.

Boggs, S.J., 2005. Petrology of Sedimentary Rocks, Second Edition, Cambridge.

Christodoulou, C. and Michailidis, K., 1990. Petrology of the plutonic suites from the Chalkidiki ophiolites, Northern Greece. Implications for parental magma characteristics and tectonic provenance, Ofioliti, 15(1), 17-44.

Christofides, G., Thimiatis, G., Koroneos, A., Sklavounos, S. and Eleftheriadis, G., 1994. Mineralogy and chemistry of Cr-chlorites associated with chromites from Vavdos and Vasilika ophiolite complexes (Chalkidiki, Macedonia, N. Greece), Chemie der Erde, 54, 151166.

Cradell, O., 2005. Macroscopic analysis and characterization of chert from Transylvania for provenance purposes, Sargetia, 33.

Crerar D.A., Namson, J., Chyi, M.S., Williams, L. and Feigenson, M.D., 1982. Manganiferous cherts of the Franciscan assemblage. I. General geology, ancient and modern analogues, and implications for hydrothermal convection at oceanic spreading centers, Economic Geology, 77, 519-540.

Grammenos, D.V., Pappa, M., Ourem-Kotsos, N., Skourtopoulou, K., Giannouli, E., Maraggou, C., Valamoti, S., Syrides, G., Makri, E. and Christidou, P., 1992. Excavation of the Neolithic settlement Thermi B and Byzantine installation despite the prehistoric settlement of Thermi A. Excavation period 1989, Macedonika KH, 381-50.

Jung, G., Mussallam, K., Burgath, K., Kockel, F., Mohr, M. and Raschka, H., 1980. Ulramafic and related rocks of Chalkidiki, Proc. Internat. Symp. Metals in Mafic and Ultramafic Complexes, vol. 3. Inst. Geol. Mining Research, Athens, Greece, 24-42.

Junguo, H., Yongzhang, Z. and Hongzhong, L., 2011. Study on geochemical characteristics and depositional environment of Pengcuolin chert, Southern Tibet, Journal of Geography and Geology, 3(1), 178-188.

Kato, Y. and Isozaki, Y., 2009. Comment on "Evaluation of palaeo-oxygenation of the ocean bottom cross the Permian-Triassic boundary" by Kakuwa (2008): Was the Late Permian deep-superocean really oxic? Global and Planetary change, Elsevier, 69, 79-81.

Mollat, H., Antoniades, P. and Ricou, L.E., 1978. Geological Map of Greece, Vasilika sheet, Institute of Geological and Mining Research, IGME.

Murray, R.W., 1994. Chemical criteria to identify the depositional environment of chert: general principles and applications, Sedimentary Geology, 90, 213-232.

Murray, R.W., Jones, D.L., Gerlach, D.C. and Russ, G.P., 1990. Rare Earth Elements as Indicators of Different Marine Depositional Environments in Chert and Shale, Geology, 18(3), 268-271.

Rapp, G., 2009. Archaeomineralogy, Natural sciences in archaeology, Second Edition, Springer.

Spray, J.G., Bebien, J., Rex, D.C. and Roddick, J.C., 1984. Age constraints on the igneous and metamorphic evolution of the Hellenic - Dinaric ophiolites, Dixon, J.E. and Robertson, A.H.F., eds., The geological evolution of the Eastern Mediterranean, Geological Society, London, Special Publications, 17, 619-627.

Yamamoto, K., 1986. Geochemical characteristics and depositional environments of cherts and associated rocks in the Franciscan and Shimanto terranes, Sedimentary Geology, 51, 65-108. 